\title{
Rum for kvalifikation, plads til inklusion? - om mødet mellem børn, rum og paedagogik i den danske folkeskole
}

\author{
David Thore Gravesen` og Lea Ringskou \\ Pedagogik og Samfund, VIA University College, Viborg, Danmark
}

\section{Resumé}

Undersøgelsesspørgsmålet for denne artikel er: Hvilke rum og roller skaber pæedagoger $i$ spendingsfeltet mellem kvalifikation og inklusion $i$ kølvandet på folkeskolereformen fra 2014? Med afsæt i etnografiske undersøgelser foretaget på to danske folkeskoler, analyserer artiklen pædagogers arbejde i den danske folkeskole efter folkeskolereformen i 2014. Analysen udfoldes gennem en undersøgelse af relationen mellem rum og pædagogik. I de empiriske data, som analysen bygger på, fremstår netop rum som væsentlig markør i forhold til de former for pædagogik, der konstituerer sig. Skolereformen åbner op for, at pædagoger inviteres ind i nye rum. Disse rum er domineret af en politisk og samfundsmæssig dagsorden om højere akademisk kvalitet og effektiv kvalifikation i skolen. I pædagogisk praksis støder denne dagsorden sammen med ambitionen om inkluderende læringsmiljøer. Mødet mellem kvalifikation og inklusion udgør et paradoks og spændingsfelt, som påvirker pædagogens praksis.

Nøgleord: Folkeskolen; fritidspœedagogik; rum; roller; etnografisk feltarbejde

\begin{abstract}
The research question in this article is: What spaces and roles do pedagogues create in the tension between qualification and inclusion after the school reform in Denmark in 2014? Based on ethnographic studies carried out in two Danish Primary Schools, the article focuses on the work of pedagogues in the Danish Primary school after a school reform in 2014. The analysis unfolds through a study of the relationship between space and pedagogy. In the empirical data on which the analysis is based, space appears as a significant marker in the various types of pedagogy that is constituted. With the school reform pedagogues are invited into new spaces. These spaces are dominated by a political and societal agenda focusing on efficiency and qualification in school. In the daily practice this agenda collides with the ambition of inclusive learning environments. The encounter between qualification and inclusion represents a paradox that affects the daily work of the pedagogues.
\end{abstract}

Keywords: Primary School; leisure-time pedagogy; space; roles; ethnographic studies

Received: February 2016; Accepted: November 2016; Published: December 2016

^Korrespondanse: David Thore Gravesen, VIA University College, Prinsens Allé 2, 8800 Viborg, Danmark, E-post: dtg@via.dk 


\section{Indledning}

I 2014 blev en ny folkeskolereform indført i Danmark. Reformen har medført flere timer på skoleskemaet for elever i 0.-9. klasse. Det øgede antal skoletimer har reduceret timerne til SFO'erne (og dermed fritidspædagogikken), hvor størstedelen af elever i $0 .-3$. klasse er indskrevet ${ }^{1}$. I forlængelse af folkeskolereformen og nye skolepolitiske prioriteringer har pædagogernes rolle ændret sig. Vores undersøgelse indikerer, at pædagogerne i dag indtager en fremtrædende rolle i klasseværelset og i de rum, hvor børnene skal lare noget.

Danske pædagoger har en lang tradition for at deltage i curriculumbaserede aktiviteter, og har $\mathrm{i}$ årevis støttet og ageret medspillere i forbindelse med børns læring. Men hvor pædagogernes fokus og tidsbrug førhen primært har været knyttet til fritidspædagogiske rum i børnenes SFO-liv, er de fleste af deres arbejdstimer i dag placeret i skolens rum i løbet af den forlængede skoledag. Med folkeskolereformen fulgte en række nye tiltag på skoleskemaet: Lektiecafe, understøttende undervisning og 45 minutters daglig motion og bevagelse ${ }^{2}$. Disse tiltag er alternative bud på, hvordan folkeskolens rum og læringsmiljøer varieres. Med de tre nævnte tiltag får pædagoger mulighed for at gå forrest og $\mathrm{i}$ et hidtil uset omfang indtage og styre klasserummet.

Artiklens undersøgelsesspørgsmål er: Hvilke rum og roller skaber padagoger $i$ spandingsfeltet mellem kvalifikation og inklusion $i$ kølvandet på folkeskolereformen fra 2014? Ud fra de etnografiske studier vi foretog på to danske folkeskoler, argumenterer vi $\mathrm{i}$ artiklen for, at pædagoger i hverdagens praksis overvejende opererer i tre forskellige slags roller. I nogle aktiviteter er pædagogerne klasserumsledere, med fokus på læringsfællesskabet og den samlede klasse. I andre sammenhænge fungerer de som omvendte bodyguards. Når lærere forestår undervisning ved katederet, positionerer pædagoger sig i denne rolle mindre centralt i klasserummet - bagtil eller i siden, hvorfra de observerer og griber ind ved forstyrrelser. Hvor en bodyguard i almindelig forstand beskytter en vigtig person fra den større gruppe, arbejder pædagogen som omvendt bodyguard med at skærme eller beskytte den store gruppe af almindeligt fungerende elever fra den eller de få forstyrrende elever i klassen. Her har pædagogen fokus på

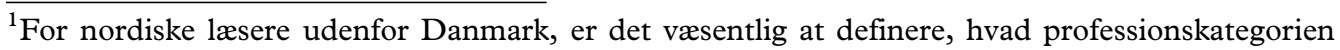
pædagog og institutionstypen SFO dækker over i dansk kontekst. I Danmark bliver man efter at have fuldført en 31/2-årig professionsbacheloruddannelse som pædagog berettiget til titlen pædagog. En titel, der giver adgang til en række meget forskelligartede jobfunktioner indenfor det pædagogiske felt, såsom dagtilbud, ungdomsklubber, området for mennesker med nedsat fysisk og psykisk funktionsevne og i dette tilfælde: skole og SFO. SFO står for Skole-Fritids-Ordning. Det er et fritids- og pasningsstilbud om morgenen forud for selve skoledagen og ikke mindst om eftermiddagen efter endt skoledag for børn i indskolingen, primært i 0.-3. klasse.

${ }^{2}$ Lektiecafé er udtryk for skemalagte timer, hvor børnene kan arbejde med lektier. Understøttende undervisning er skemalagte timer, der ligger ud over de faste fag. Her kan arbejdes i dybden med fagene, elevernes læringsparathed, sociale kompetencer, motivation og trivsel. Med reformen er der derudover krav om at elever skal bevæge sig mindst 45 minutter hver dag, udover den almindelige gymnastikundervisning. Hvordan motion og beveegelse praktiseres, er op til den enkelte skole.
} 
at håndtere den enkelte, så fællesskabet får bedst mulige arbejdsbetingelser. Endelig fungerer pædagoger i forskellige sammenhænge som vilkårlige omsorgsgivere, både undervejs i den skemalagte skoledag og i de mindre strukturerede SFO-timer om morgenen og om eftermiddagen. Her tager de udgangspunkt i børnenes individuelle behov, perspektiver og samlede trivsel, når de leger, snakker og trøster. Rollen som omsorgsgiver har tidligere fyldt mere, men med folkeskolereformens skærpede fokus på kvalifikationer, mere effektiv læring og mere fugtbart udbytte, bliver det mere vilkårligt, hvornår denne rolle aktiveres.

Vores empiriske data demonstrerer, at folkeskolereformen har stor betydning for de roller pædagoger aktiverer og ikke mindst de pædagogiske rum, der skabes. Det er denne sammenhæng, artiklen belyser. At forskere finder det relevant og vigtigt at studere sammenhænge imellem rum og pædagogik, er der i dansk kontekst flere eksempler på. Hvor Coninck-Smith (2005) har fokuseret på historiske perspektiver på sammenhængen imellem arkitektur og læring, har Juelskjær (2008) interesseret sig for, hvordan pædagogisk arkitektur (f.eks. bygninger, mure, vægge, glas, rumfordelinger, borde, stole, etc.) spiller sammen med pædagogisk praksis og subjektivering - eller såkaldt elevproduktion - i hverdagslivet i folkeskolen. Larsen (2005) konstaterer, at arkitektur og artefakter "ordløst medvirker til at regulere mennesker, deres handlinger og relationerne imellem dem" (Larsen, 2005, s. 9). Gulløv og Højlund (2005) fremhæver, at studiet af institutionelle rum kan fortælle noget om magtfordelinger, hierarki og meningsdannelse, og inddragelsen af rum og materialitet i studier af børns hverdagsliv kan således være en vigtig kilde til forståelse af det sociale. I en bredere nordisk kontekst indgår rum ligeledes i interessante analyser; "Vi må samtidig analysere, hvad rummet gør ved os og hvad vi gør med det", konstaterer Ehn \& Löfgren (2006, s. 103) og Lidén (2000) fremsætter, at "samfunnets mange institusjonelle praksisser ikke bare har en historisk, men også en geografisk dimensjon; de er forankret i rom og de er med på å reprodusere rom. Gjennom den fysiske utformningen av skolebygningen formidles foreskrevne handlemåter" (Lidén, 2000, s. 91).

Med artiklen ønsker vi at bidrage til den videre produktion af viden omkring sammenhængen mellem rum og pædagogik, herunder ikke mindst hvilken betydning et øget fokus på kvalifikation har for ambitionerne om inklusion, når pædagoger forvalter deres roller i den danske folkeskole. I det følgende ser vi nærmere på ambitionerne bag reformen.

\section{Folkeskolereformen - en bastard med modstridende ambitioner?}

Folkeskolereformen 2014 er i høj grad reaktion på utilfredsstillende danske placeringer i internationale sammenligninger af skoleelevers testresultater, for eksempel i PISA-tests ${ }^{3}$.

\footnotetext{
${ }^{3}$ Den første test blev gennemført i 2000 og har herefter fundet sted hvert tredje år. I følgende artikel fremgår det klart, at den første test sendte Danmark i chok over de dårlige resultater, idet Danmark, sammenlignet med andre lande, bruger mange penge på uddannelsessystemet: https:// www.folkeskolen.dk/513321/danmark-er-et-pisa-chok-land
} 
Forud for reformen skuffede særligt resultaterne i dansk og matematik, og hverken stærke eller svagere elever vurderedes at have opnået tilfredsstillende fagligt udbytte ${ }^{4}$. En grundlæggende målsætning er, at reformen skal styrke alle elevers faglige kunnen, uanset herkomst og social og kulturel ballast. Forud for reformen formulerede Kommunernes Landsforening ${ }^{5}$, at danske skoler skulle rangere i top fem på listen over verdens bedste skoler, gennem forbedrede akademiske resultater og større effektivitet (Knudsen, 2010). Politikerne bakkede op, og i aftalen, der ligger til grund for reformen, formulerede de: "Via mere og bedre undervisning skal eleverne på sigt kunne det samme i 8. klasse, som de i dag kan i 9. klasse"6.

Samtidig var intentionen med folkeskolereformen at styrke inklusionen. Tilbage i 2012, to år før folkeskolereformen, blev der vedtaget en lov om øget inklusion ${ }^{7}$. Målet var, at børn med særlige behov, der tidligere var placeret i støtte- eller specialpædagogiske sammenhænge, skulle være en del af det almene klasserum. Et mål, der blandt andet havde til hensigt at nedbringe de stigende udgifter til et stadig voksende antal børn henvist til specialundervisning i folkeskolen (Hansen \& Qvortrup, 2013). I pædagogisk praksis lanceres inklusionsbegrebet ofte som afløser til integration (Hansen, 2006). Fremfor et individorienteret fokus, hvor den enkelte i høj grad skal tilpasse sig fællesskabet, skal den inkluderende praksis ideelt set rette fokus mod den samlede pædagogiske praksis og udviklingen af denne. Der skal etableres differentierede fællesskaber, hvor forskellighed betragtes som en ressource (Kornerup, 2009; Buus, 2014). I nogle sammenhænge præges den danske debat og forskning dog af en for ensidig interesse for elevernes faglighed og læreres og skolelederes praksis (Alenkær, 2009; Dyssegaard, 2009). Inklusion som middel og mål rækker netop ud over undervisningen og fordrer opmærksomhed på og arbejde med elevernes færden på tværs af alle de forskellige fællesskaber gennem dagen; i klassen, i frikvarteret, i SFO'en, etc. (Stanek, 2012a, 2012b; Dyssegaard, Larsen $\&$ Tiftikci, 2013). Kommunernes Landsforening har argumenteret for, at med den varierede undervisning og kravet om 45 minutters daglig motion og bevægelse giver bedre muligheder for inklusion (Thomsen, 2014).

Reformen indeholder således både ambitioner om bedre kvalifikationer og mere inkluderende læringsmiljøer. I artiklen belyser vi pædagogens rolle(r) i spændingsfeltet imellem kvalifikations- og inklusionsbetræbelserne. Induktive læsninger af vores empiriske materiale illustrerer rum som en betydningsfuld markør i dette arbejde. For konkret pædagogisk arbejde finder altid sted og iværksættes i rumlige sammenhænge.

\footnotetext{
${ }^{4}$ Se den politiske aftale der ligger til grund for folkeskolereformen her: http://www.kl.dk/ ImageVault/Images/id_62271/scope_0/ImageVaultHandler.aspx

${ }^{5}$ En dansk interesse- og medlemsorganisation for alle 98 kommuner i Danmark (http://www.kl.dk/)

${ }^{6}$ Se: http://www.kl.dk/ImageVault/Images/id_62271/scope_0/ImageVaultHandler.aspx

${ }^{7}$ Se: https://www.retsinformation.dk/forms/r0710.aspx?id=141546\&exp=1
} 


\section{Metodologisk afsat}

Analysernes metodologiske afsæt er en kvalitativ undersøgelse, vi foretog i to danske folkeskoler i $2014 \mathrm{og} 2015^{8}$. I efteråret 2014 fulgte vi ${ }^{9}$ fire pædagoger og gennemførte etnografiske observationer (Hastrup, 2010; Kristiansen \& Krogstrup, 1999; Spradley, 1980). I observationerne var vi optagede af pædagogernes rolle og aktiviteter i både skolen og SFO'en. Om end vi foretog undersøgelserne i folkeskolens rum, var det ikke samarbejdet og positioneringerne mellem pædagogerne og lærerene, der var i fokus, selvom vi i feltarbejdet ofte mødte lærerne, når vi fulgte pædagogernes arbejdsdag. Idet vi ikke har haft specifikt fokus på relationerne imellem pædagogerne og lærerne, tillægges denne del ikke væsentlig betydning i analyserne.

Begrebet deltagelse er centralt for Kirsten Hastrup, når hun diskuterer feltarbejde. Det er netop gennem deltagelse, at man kan opnå viden, og "uanset fra hvilken plads man deltager, gælder det, at deltagelse er en forudsætning for at mærke og forstå de drivende kræfter i det sociale felt" (Hastrup, 2010, s. 71). Hastrup beskriver ligeledes at stedet er centralt (Hastrup, 2010), og at det studerede ikke kan betragtes eller forstås løsrevet fra landskabet eller det fysiske rum. Sociale fællesskaber finder sted - og imellem steder er der ruter, som også kan være betydningsfulde. Inspireret af sådanne pointer fulgte vi i løbet af feltarbejdet ${ }^{10}$ pædagogerne tæt $\mathrm{i}$ løbet af deres arbejdsdage; fra timerne i morgen-SFO'en, over i skolens undervisningsaktiviteter til fritidspædagogikken i eftermiddags-SFO. De mange forskellige rum og lokaliteter gav anledning til at foretage såkaldte krydsperspektiveringer af pædagogernes roller og bevægelser (Hastrup, 2010), og derved åbnede der sig omfattende viden om feltets spilleregler.

Gennem feltarbejdet bevægede vi os igennem forskellige grader af opmærksomhed. Kristiansen og Krogstrup (1999) sondrer mellem den beskrivende, den fokuserede og den selektive observation. Gradvist skærpedes vores opmærksomhed fra først at være orienteret mod det generelle spørgsmål: "Hvad sker der her?", til med tiden at blive mere fokuseret på specifikke kategorier, praktikker og spørgsmål. Her fokuserede vi på kategorierne tid, rum og relation. I den sidste selektive fase koncentrerede vi indsatsen

\footnotetext{
${ }^{8}$ De to skoler ligger i hver deres ende af en større dansk provinsby. For at sikre anonymitet er navne på skoler, informanter og elever ændret.

Bøgeskolen er en mellemstor kommunal skole med cirka 500 elever fordelt på 0.-9. klasse. SFO'en er dels lokaliseret $\mathrm{i}$ en selvstændig bygning for de mindste SFO-børn, dels i lokaler i skolens bygninger. Pædagogerne anvender den selvstændige bygning til møder og planlægning. Det er her SFO'ens leder og souschef har kontor. På Bøgeskolen er der ansat omkring 10 pædagoger, som arbejder på tværs af skole og SFO, samt en SFO-leder og en souschef.

Nordskolen er ligeledes en mellemstor kommunal skole med cirka 500 elever fordelt på 0.-9. klasse. SFO'en overtager om morgenen og eftermiddagen skolens lokaler og børnene opholder sig desuden i de to skolegårde og på de omkringliggende græsfodboldbaner. Pædagogerne har eget personaleværelse i skolebygningen, hvor de forbereder sig, holder møder og pauser. På Nordskolen er der ansat omkring 5 pædagoger og 2 pædagogmedhjælpere, der arbejder på tværs af skole og SFO, samt en SFO-leder.

${ }^{9}$ Artiklens to forfattere og fire studerende deltog i forskningsprojektet og foretog deltagende observationer. De studerende deltog ligeledes i opfølgende fokusgruppeinterviews.

${ }^{10}$ Feltarbejdet varede godt to måneder med observationer fordelt på aftalte dage igennem hele perioden.
} 
fuldstændigt om de praktikker og spørgsmål, som direkte relaterede sig til disse kategorier. I undersøgelsesarbejdet positionerede vi os oftest som moderat deltagende (Spradley, 1980), det vil sige vekslede imellem at sidde, stå eller gå og observere, for undertiden at deltage $\mathrm{i}$ forskellige aktiviteter, når det virkede oplagt og naturligt. Sjældnere var vi aldeles ikke-deltagende eller fuldstændigt involverede.

Ud over feltnoter fra observationerne består vores datamateriale af informanternes dagbogsnotater og data fra opfølgende interviewsamtaler. Inden vi indledte observationer, udstyrede vi informanterne med dagbøger, hvori de noterede daglige oplevelser, overvejelser og bekymringer. Interviewene foretog vi som fokusgruppeinterviews (Halkier, 2002). De forskellige dataindsamlingsmetoder gav os et nuanceret indblik i informanternes handlinger, refleksioner og ytringer.

Vi er bevidste om indvendinger imod kvalitativ forskning, angående sådanne studiers lokale og subjektive karakter. Dette er dog netop styrken ved det kvalitative approach (Kvale \& Brinkmann, 2008; Small, 2008), og designet af vores undersøgelse og diskussionerne $\mathrm{i}$ artiklen her, bunder således ikke i ambitioner om repræsentativitet og generalisérbarhed, men nærmere i ønsket om at deltage i den fortsatte refleksion over pædagogers rolle i skole- og fritidspædagogikken i Danmark.

\section{Teoretisk udgangspunkt}

Det teoretiske udgangspunkt for vores analyser er Kirkeby, Gitz-Johansen \& Kampmann (2005), der har beskæftiget sig med samspillet mellem fysiske rum og pædagogiske processer. Kirkeby, Gitz-Johansen og Kampmann opererer med distinktionen imellem blød og hård funktionalisme $\mathrm{i}$ analyser af henholdsvis hårdt og svagt kodede pædagogiske rum. Denne sondring er relevant i forhold til vores data, idet netop forskellen imellem rummet i skole og SFO markerer centrale forskelle, der har betydning for pædagogens rolle og relationer til børnene. Sådanne forskelle angår ikke blot konkrete rum på konkrete skoler, men markerer centrale spørgsmål vedrørende udviklingen af pædagogiske og politiske prioriteringer i fremtidens skole i Danmark. Et centralt ærinde for artiklen er, at belyse hvordan pædagoger dagligt håndterer sådanne aktuelle prioriteringer i pædagogikkens hverdagsrum.

Hertil benytter vi pointer fra Foucaults Overvågning og Straf (Foucault, 2002/1975). Foucaults arbejde er relevant i forhold til analysen af, hvordan pædagoger bruger rum som element $i$ en disciplinerende pædagogik, der opererer med inddelinger, afskærmninger og overvågning som centrale redskaber i arbejdet med kvalifikation og inklusion. I det afsluttende afsnit Rum for kvalifikation, plads til inklusion? - afsluttende diskussioner af et paradoks inddrager vi Biesta's $(2011,2015)$ diskussioner om uddannelse $\mathrm{i}$ forhold til at forstå, hvordan pædagogernes roller kan betragtes $\mathrm{i}$ et større uddannelsespolitisk perspektiv. Vi diskuterer pædagogernes arbejde som udtryk for både kvalifikation, socialisation og subjektifikation, men betoner, at det aktuelle politiske og pædagogiske fokus på kvalifikation har mærkbar betydning for balancen $\mathrm{i}$ skole- og fritidspædagogikken og følgelig pædagogernes reelle muligheder for at arbejde inkluderende. 


\section{Analyse}

De kommende tre analyseafsnit er disponeret omkring de næunte roller: klasserumsleder, omvendt bodyguard og vilkårlig omsorgsgiver. I analyserne knytter vi rollerne til de rum, hvor pædagogikken aktiveres og diskuterer, på hvilke måder rummene og rollerne bidrager til at løfte ambitionerne om henholdsvis øgede kvalifikationer og inkluderende læringsmiljøer.

\section{Pædagogen som klasserumsleder}

Pædagogen Joan er primært tilknyttet 1.b på Nordskolen. En del af tiden tilbringer hun sammen med børnene i klasselokalet, hvor hun på egen hånd har Understøttende undervisning, Lektiecafe samt motion og bevagelse. I løbet af ugen har hun derudover timer med klasselæreren. Klasselokalet er kvadratisk. På væggene og i snore ned fra loftet hænger bogstaver og billeder fra klassiske børnebøger. Over døren hænger et ur. Der er sat to-mandsborde op i rækker. Bordene fylder det meste af lokalet. Et whiteboard er placeret centralt i front af klasselokalet og, bordene er rettet mod det. Ude i siderne af whiteboardet hænger der blandt andet danskfaglige billeder, bogstavrim, påmindelser ( $\mathrm{fx}$ huskeregler omkring udsagnsord), skoleskema og skilte med tal og matematik. Bagerst i lokalet har børnene deres skuffe med bøger og mapper i.

Feltnotatet beskriver indretningen af et klasselokale på en af skolerne. Indretning og interiør er typisk for skolernes øvrige klasselokaler. Klasselokalet som selvstændig rumkategori konnoterer skole og faglighed. Ved hjælp af bordenes og stolenes opstilling, tavlens centrale placering og de faglige artefakter placeret rundt om i rummet signaleres, hvad der foregår, og hvordan rummet skal anvendes. Klasselokalet som rum kan kategoriseres inden for kategorien hård funktionalisme, idet "brugsmåderne er veldefinerede og ikke umiddelbart står til forhandling" (Kirkeby, Gitz-Johansen \& Kampmann, 2005, s. 50). For eksempel er det på Nordskolen ikke tilladt for børnene at være i klasselokalet i frikvarteret, hvilket indikerer rummets funktionsbestemmelse og kodning. Ligesom alle andre rum, udgør indretningen af klasselokalet en vigtig dimension $\mathrm{i}$ forhold til hvilket mulighedsfelt, den rumligt indrammede pædagogik udstikker. Hvilke aktiviteter fremmes i rummet, og hvilke hæmmes? Feltnotatet illustrerer, hvordan rummets indretning inviterer til stillesiddende læringsaktiviteter og rolig kropsføring med tavlen som fælles omdrejningspunkt.

Når pædagogerne varetager undervisning alene, synes rum og pædagogik at understøtte og løbende (re)producere hinanden. Som klasserumsleder placerer pædagogen sig centralt i rummet og leder i 45 minutter an ud fra et specifikt fagligt mål og en konkret plan, der skal sikre at målet nås. Ligesom rummet i sig selv gennem den hårde funktionalisme markerer rettethed og inviterer til koncentration og fokus, bærer pædagogernes handlinger i og samspil med rummet præg af rettethed og stærk intentionalitet. Pædagogerne anvender mimik, gestik, signaler og ritualer til at fastholde rettetheden og matcher rummets funktioner og mulighedsfelt; en bestemt leg, der leges, når den ene time skal afsluttes og en ny begynde, forskellige klapperytmer når børnene skal tie, lynlåssignal for mund, der skal lukkes, brug af fløjte med videre. 
I følgende eksempel indtager pædagogen Karen på Bøgeskolen rollen som klasserumsleder i matematik i 1. klasse:

'Nu skal vi i gang med side 54 - det er et helt nyt emne. Minus betyder man får mindre'. Karen læser op fra bogen. Hun irettesætter Viktor og en pige: 'Det er vigtigt det her!' Når hun skriver noget op på tavlen, med ryggen til eleverne og samtidig stiller et spørgsmål, så rækker hun højre hånd i vejret for at indikere, at hvis man vil svare, skal man række hånden op. (...) da der er en, der snakker, laver hun lynlåsbevægelse hen over læberne for at indikere, at man skal være stille.

Signalerne og ritualerne kan betegnes som såkaldte indarbejdede kommandolinjer, som er særligt "effektive når koordineringen er automatisert gjennom innlæring av og reaksjon på signaler" (Lidén, 2000, s. 157). Koncentration og rettethed bibeholdes ligeledes $\mathrm{i}$ en del af de situationer i klasserummet, hvor den faglige læring ikke dominerer. For eksempel i spisesituationer på Nordskolen med pædagogen Michael: "Tobias, aftalen går på, vi skal sidde på pladserne! Albert, så bruger vi munden til at spise med - og ikke snakke!”

I værket Overvågning og Straf (Foucault, 2002/1975), under overskriften Inddelingens kunst, diskuterer Foucault, hvordan disciplineringsinstitutioner, herunder skoler, opererer med at fordele individerne i rummene, ofte ved at placere dem i et aflukke. "Til hvert individ sin plads, og på hver plads et individ. Undgå at opdele gruppevis, opløs de kollektive størrelser, analyser de vage, massive eller uhåndgribelige flerheder", formulerer Foucault, og fortsætter; "Det er nødvendigt at fjerne virkningerne af ubestemte fordelinger, individernes ukontrollerede forsvinden, deres diffuse cirkulation, deres uanvendelige og farlige koagulering" (Foucault, 2002/1975, s. 159). Om end Foucault skrev dette $i$ en anden kulturel og epokal sammenhæng, synes pointerne rammende, når man betragter pædagogernes arbejde som klasserumsledere. Her indtager pædagogerne en central rolle i den disciplinering, som skolelivet også repræsenterer. I klasserummet, eller aflukket, iværksættes de inddelinger, fordelinger og aktiviteter, der synes nødvendige for at opretholde den orden, som skal til for at opnå de faglige mål (se også Lidén, 2000, s. 157).

Med blikket rettet mod klassen som helhed, overvejer pædagogerne, hvilke pædagogiske initiativer og hvilken brug af rummet, der kan bidrage til at flest muligt får et højt læringsudbytte. Overvejelserne afspejler udfordrende dilemmaer knyttet til inklusionsdagsordenen. Michael formulerer:

Du sidder i et dilemma. Du har 19 andre her. Og så vælger man... og det mener jeg jo et eller andet sted, man er nødt til... så vælger man de 19 (...). Du er jo nødt til at vælge flertallet frem for den ene, der ikke kan finde ud af det.

Som praktisk respons på sådanne udfordringer anvender pædagogerne klasserummets indretning, interiør og børnenes placering i rummet til at skabe ro. Ofte sker det ved at børn, der ikke sædvanligvis forstyrrer undervisningen, fordeles ved de almindelige borde- og stoleformationer i rummet, imens mere urolige børn placeres på andre måder. I en af klasserne sidder denne kategori af børn oppe foran eller ude i siden, med hovedet ind mod væggen: 
Lise sidder på en taburet alene ved et enmandsbord, der er placeret så det støder op mod tavlen. Når hun sidder på stolen kigger hun direkte ind i tavlen (...). Simon sidder også alene ved et bord, på forreste række, ude i siden, med hovedet mod væggen.

I en anden klasse eksperimenterer pædagogerne med at bruge pigerne som en slags rumlig afskærmning imellem urolige drenge. Buffere kalder de det, og pædagogen Karen forklarer: "Når vi sætter en dreng her og en dreng her og så en pige, så er det sværere at have en hel masse kørende, som ikke har noget med undervisningen at gøre”. Karen pointerer, at hun er ked af denne inddelingsmåde, da pigerne jo også har et naturligt og legitimt behov for at sidde ved siden af hinanden og styrke deres relationer. Som buffer er det ikke muligt. I en anden klasse placeres klassens fire mest urolige drenge i hvert deres hjørne af klassen, ud fra en erfaring om, at jo længere de fire er fra hinanden, jo bedre vil forudsætningerne for læring være. Borde, stole og børnenes kroppe anvendes som redskaber i den rumlige disciplinering, der bidrager til en pædagogisk orden. Uroskabende adfærd og forstyrrende snak forsøges tæmmet og relationen imellem rum, krop og pædagogik bekræfter en forståelse af sammenhængen mellem en siddende kropsstilling og en udbytterig læreproces. En forståelse, der kan spores i følgende uddrag fra Karens dagbog om arbejdet med en dreng, der skaber uro på Bøgeskolen:

Vi har flyttet ham til en ny plads og har været tydelige over for ham om, hvad den plads skal hjælpe ham til og om hvordan, det er meningen han fysisk skal sidde på stolen.

I eksemplet spiller stolen og den fysiske placering i rummet en central rolle i forhold til den aktiverede pædagogik. Rummet bliver medspiller i det adfærdsregulerende rum, som pædagogerne bidrager til at indrette. Igennem sådanne teknikker manifesteres skolens magtstruktur (Foucault, 2002/1975) og elevernes mulighedsrum.

Der er dog tilfælde, hvor pædagogen vælger at trodse klasselokalets hårde funktionalisme og midlertidigt bryde med den stærke kodning. Nogle af de tidspunkter, hvor dette sker, er i den understøttende undervisning eller i forbindelse med motion og bevagelse. For eksempel bliver stole og borde $\mathrm{i}$ et tilfælde rykket ud i siden af klasselokalet, så rummets mulighedsfelt udvides og inviterer til bevægelse og leg. I sådanne tilfælde synes disciplineringsaspektet at træde mere i baggrunden til fordel for en momentan vægtning af et varieret og mere inkluderende læringsmiljø.

\section{Pædagogen som omvendt bodyguard}

Rollen som klasserumsleder er blot én af pædagogens roller. På andre tidspunkter indgår pædagogerne $\mathrm{i}$ undervisningssituationer sammen med en lærer. Her glider pædagogen fra klasserumslederrollen over i rollen som omvendt bodyguard. En stor del af tiden tilbringer pædagogen nu i siden af rummet, bagerst eller cirkulerende rundt mellem elevernes borde og stole, mens læreren indtager den centrale placering som klasserumsleder. Især placeringen i siden eller bagtil i rummet gør det muligt for 
pædagogen at observere børnene, mens de arbejder og lytter til læreren. Her en observation fra Bøgeskolen:

Da timen begynder går pædagogen Amanda ud i siden af lokalet, hvorfra hun observerer børnene. Læreren Lisbeth begynder at krydse børnene af og tjekke, hvornår de skal hjem $\mathrm{i}$ dag. Lisbeth instruerer i dagens opgave. Børnene skal $\mathrm{i}$ grupper hjælpe hinanden med at finde frem til, hvilken tekst, der hører til hvilket billede $\mathrm{i}$ bogen, så bogen atter kan samles - som et slags puslespil. Anton arbejder alene, mod sin vilje. Ingen vil være sammen med ham, da han spørger ud i rummet. Amanda hjælper ham i gang med opgaven, forklarer en ekstra gang, skiller billeder og tekst ad for ham i to separate bunker. Hun går videre. Flere gange er hun henne ved Anton igen. Anton virker i tiltagende grad frustreret og sidder uroligt. Han vender sig om, smider papirer på gulvet hos den dreng, der sidder bag ham. Læreren siger højt: 'Anton, det er bare slet ikke i orden!' Amanda kommer hen til ham, samler papirer op og begynder at læse med ham. Efter nogle minutter er Anton stadig frustreret og sidder med tårer i øjnene. Amanda læser højt og hjælper ham med, hvilke billeder der matcher. Hun har placeret sig på en stol ved ham.

Feltnotatet leder tankerne tilbage til Foucault og begrebet panoptisme (Foucault, 2002/1975). Foucaults refleksioner omkring panoptikon med udgangspunkt i fængsler angik en bygnings arkitektoniske konstruktion og de muligheder en bestemt konstruktion giver for (potentiel) overvågning. I rollen som omvendt bodyguard synes pædagogen bogstavlig talt at personificere panoptikon. Når pædagogen umærkeligt bevæger sig rundt i siden af klasserummet eller befinder sig bagerst, kan børnene potentielt hele tiden tilses, uden at de, eftersom de som regel har hoved og øjne rettet imod tavlen, selv kan se pædagogen. Den omvendte bodyguard er således en forebyggende funktion, der praktiserer, hvad Foucault kalder den hierarkiske overvågning, hvor børn nøje observeres i rummet og vurderes i forhold til hinanden. Hertil er den omvendte bodyguard en sanktionerende funktion. For at videreføre den Foucaultske terminologi, gør pædagogen efterfølgende, i varierende omfang og i tilfælde af problemer med cirkulation og uro, brug af den normaliserende sanktion igennem omrokeringer, afskærmninger og i sjældnere tilfælde ved helt at vise børnene ud af klasserummet - enten alene eller flankeret af pædagogen. Såvel rollen som klasserumsleder som den omvendte bodyguard indeholder således overvågende og sanktionerende elementer. En vigtig forskel på rollernes fokus er jo dog, at pædagogen i rollen som klasserumsleder har fokus på læring i fællesskabet og således sjældnere fokuserer på den enkelte elev. Som omvendt bodyguard derimod, får pædagogen, qua lærerens tilstedeværelse, betragteligt mere tid og rum til at arbejde koncentreret med den enkeltes adfærd, mens læreren varetager den faglige læring i fællesskabet.

I feltnotatet ovenfor indtager Amanda rollen som omvendt bodyguard. Hendes rumlige placering gør det muligt at observere, og hurtigt bliver det klart for hende, at Anton kan komme til at skabe uhensigtsmæssig uro. Hun kredser om ham og forsøger at forebygge uroen. Gradvist glider rollens funktion over i at være mere fokuseret på at minimere den uro, der trods forebyggelsesbestræbelserne alligevel opstår omkring Anton. I den sidste del af timen sidder Amanda ved Anton. Støtten virker dobbelt. Den sikrer Antons progression i det faglige arbejde, samtidig med at den rumligt 
afskærmer ham fra at forstyrre de andre børn. I rollen som omvendt bodyguard balancerer pædagogen således sin evne til at give faglig og emotionel støtte med den overordnede ambition om at skabe ro i klasserummet. Rollen kan således ikke betragtes entydigt, idet de sanktionerende og adfærdsregulerende elementer komplementerer faglig og emotionel støtte i et relationelt konglomerat af rum, pædagog og barn.

På et overordnet samfundsmæssigt plan angår den pædagogiske intention - og inklusionsbestræbelserne - at præge de enkelte elever og kollektivet, så delene (de enkelte elever) kan fungere i et relationelt hele. I et Foucaultsk perspektiv indbefatter det disciplinerende aspekt overvågningsmåder og normaliserende sanktioner, som installeres i de enkelte individer som former af selvdisciplinering:

Deraf kommer panoptikkens vigtigste virkning: sætte den indsatte i en bevidst og permanent tilstand af synlighed, som sikrer magtens funktion. Sørge for at overvågningen har permanente virkninger, selv om den ikke er en kontinuerlig handling. Sådan at magtens perfektion har en tendens til at gøre den aktuelle udøvelse overflødig. Sådan at dette arkitektoniske apparat kunne være en maskine til at skabe og opretholde en magtrelation uafhængigt af dem, der udøver den. Kort sagt: at de indsatte bliver fanget i en magtsituation, som de selv er bærere af (Foucault, 2002/ 1975, s. 218).

Selvdisciplinering, med normalisering og effektivitet som implicitte mål, udgør i rollen som omvendt bodyguard en væsentlig del af pædagogens opgave, intention og praksis. Det bevirker, at inklusionsbestræbelserne i overvejende grad bliver (reduceret) til et spørgsmål om elevens selvinklusion. Begrebet selvinklusion dækker over elevens evne til at inkludere sig selv i fællesskabet (Khawaja \& Knudsen, 2015). I rollen som omvendt bodyguard opererer pædagogen således ofte ud fra et individ-orienteret perspektiv, som endda ofte overlades til den enkelte elev, fremfor at rette fokus imod den samlede pædagogiske praksis og udviklingen af et mere inkluderende fællesskab, sådan som de grundlæggende principper i inklusion egentlig foreskriver.

\section{Pædagogen som vilkårlig omsorgsgiver}

En tredje og væsentlig rolle, pædagogen indtager, er rollen som vilkårlig omsorgsgiver. Inklusionsopgaven, omsorgs- og relationsarbejdet og interessen for børnenes trivsel og sociale udvikling er centrale elementer i pædagogernes selvforståelse. I et fokusgruppeinterview fortæller Karen om, hvad hun betragter som det værdifulde i arbejdet:

(...) det er at følge børnene fra de starter i 0. klasse - jeg har fulgt mange børn - og opbygget den der tætte, tætte relation, fordi (...) man kommer rigtigt ind under huden på dem og ind under huden på deres familier og følger hvordan de udvikler $\operatorname{sig}(\ldots)$.

I en uformel samtale i løbet af observationsstudierne forklarer Michael, hvordan kontakten til den enkelte er altafgørende i arbejdet, og hvordan det efter reformen er sværere at finde rum til det relationelle og omsorgsbaserede fokus. 
Timerne i SFO-delen foregår oftest i rum kendetegnet ved blød funktionalisme og svag kodning. SFO-rummene er mere "åbne" end skolens voksendefinerede rum. Her er små kroge, børnene kan starte en leg op i, bløde sofagrupper og store runde borde med stole omkring, hvor børnene selv kan bestemme, hvad de har lyst til at lave (lege med perler, spille brætspil, tegne, etc.). Michaels mulighed for at møde børnene i forlængelse af børnenes egne kreative fortolkninger og mere frie anvendelse af rummene, er dog mindsket på grund af reduktionen af arbejdstimer i SFO-delen. Dette har betydning for muligheden for at knytte an og skabe kontakt til børnene. Én til én-relationer og øjenkontakt med børnene er afgørende, indikerer Michael, men rummet til det, kan han sjældnere finde: "Man skal være der... (...). Hvis de oplever, man ikke er der, så daffer de af igen", forklarer han. Michaels udsagn illustrerer den vilkårlighed, folkeskolereformen og de indskrænkede SFO-rum har tilført rollen som omsorgsgiver. Vi vælger netop adjektivet vilkårlig foran substantivet omsorgsgiver, idet rollen aktiveres vilkårligt, når rummet og tiden tillader det. Rollen træder oftest frem $\mathrm{i}$ SFO-tiden, om end den også er i spil i klasserummene og i forbindelse med den formelle del af skoledagen.

Også Joan lægger vægt på den mindre formaliserede og knapt så funktionsstyrede rolle som vilkårlig omsorgsgiver. I følgende situationen fra Nordskolen har Joan morgenvagten i SFO'en. Morgenvagten foregår i fællesrummet, som anvendes i SFO-tiden:

Da jeg (observatør) kommer ind af døren klokken 6.30 er der, foruden Joan, to børn tilstede. Der er stille i rummet. Den ene dreng sidder og spiser morgenmad. Joan sidder der også. Pigen Simone sidder ved et langt bord i siden af rummet med sin i-Pad foran sig og høretelefoner på. Der er tændt stearinlys. Morgenmadsbordet er dækket ved siden af det lille køkken ude i fællesrummet. Klokken 6.45 kommer Nicklas. Han sætter sig ved morgenbordet. Nicklas læner sig frem mod Joan, som han sidder ved siden af og hvisker til hende om dagen i går. Joan hvisker tilbage, men så tilpas højt, at jeg (observatør) kan høre det: 'Hvorfor var det en god dag i går?' (...) Joan og Nicklas sidder tæt, kigger meget på hinanden i samtalen, deres arme rører hinanden.

Idet rollen som omsorgsgiver især kommer i spil og får plads i SFO-rummene, udspiller rollen sig oftest i SFO'ens lokaler. På Nordskolen er SFO'ens primære rum det ovenfor nævnte fællesrum. Det store lokale er svagt kodet og indikerer et langt mere varieret mulighedsrum, end tilfældet er med klasserummene. På Bøgeskolen er to klasselokaler lagt sammen til de børn fra 2. og 3. klasse, der går i SFO. Dertil kommer, at børnene i 0. klasse og 1. klasse på Bøgeskolen har en selvstændig SFO bygning på den anden side af skolegården. Både de to sammenslåede klasselokaler og den selvstændige SFO bygning er, ligesom fællesrummet på Nordskolen, mere hjemligt indrettet end klasselokalerne. Her er hylder med spil og legesager, store runde borde man kan sidde omkring, plakater og et bredt udvalg af let tilgængelige kreative materialer. Ofte indleder pædagogerne en aktivitet, som børnene frivilligt kan deltage i. Andre gange involverer pædagogerne sig i de lege og aktiviteter, børnene selv har sat i gang. 
Et eksempel på den variation og friere fortolkning, som børn og pædagoger anvender i SFO-rummene på Bøgeskolen, er en række små rum eller båse bagest $\mathrm{i}$ et af SFO-rummene. De små båse kan slås sammen til større rum, lukkes og åbnes imod hinanden. Én dag bliver en bås brugt til at slæbe en sofa ind og sidde og læse. En anden dag bliver et sammensat rum brugt til rolleleg, og en tredje dag har nogle børn helt ryddet den lille bås, lukket godt til og sidder så på gulvet med deres iPads. De fleksible muligheder signalerer ikke, som i klasserummet, krav om rettethed og fagligt fokus. Mulighedsrummet er et andet, overvågning er mindre udtalt og konstellationen rum, pæedagog, barn indikerer her nærmere invitation til selvstændig fortolkning, plads til forskellighed og mere inkluderende samværsformer (Madsen, 2009). Hertil frigiver den bløde funktionalisme rum og tid til børnenes indbyrdes relationelle tilknytning og pædagogens rolle som omsorgsgiver.

Rollen som vilkårlig omsorgsgiver er ikke eksklusivt reserveret til SFO-rummene. Pædagogerne bærer også det relationelle omsorgsarbejde ind i skolerummet. Men idet den dominerende agenda i løbet af skoledagen er curriculum og læring, fremstår omsorgsarbejdet her mere vilkårligt. I metaforiske vendinger kan man sige, at pædagogerne i skolerummet stjæler sig tid til at aktivere rollen som omsorgsgiver og således få kilet deres fokus på inklusion og trivsel ind i små sprækker. Pædagogerne forsøger at præge eller balancere klasserummenes hårde funktionalisme med en blødere agenda, som de vægter højest. Karen fortæller, at hun betragter det skolefaglige som sekundært, idet børn der ikke trives i relationerne har svært ved at få et fagligt udbytte.

Nogle gange er der tale om, at pædagogerne bevidst omdanner klasserummet til et rum for omsorg og umiddelbar relationel tilknytning. I sådanne tilfælde træder rummets stærke kodning i baggrunden. For eksempel har Amanda bevidst valgt at bruge en del af sin forberedelsestid til de faglige timer til at møde 10 minutter før timens begyndelse og small-talke med eleverne:

Jamen jeg kan godt vælge at komme, når timen begynder. Men jeg vælger altså at komme lidt før (...). Når jeg vælger at gå derned ti minutter før, så går min tid med det og det går jo fra min pause, forberedelse osv. Men de der ti minutter inde i klassen, de er bare så vigtige (...). Det skal være sådan at de føler sig velkomne, føler sig set, når de kommer ind i klassen. Det giver så meget.

I andre tilfælde er der tale om, at pædagogen direkte bryder med skoleskemaets formelle program og kaprer mulighedsrummet. I følgende eksempel er eleverne i 1. klasse på Nordskolen ved at tage en test. Joan er til stede sammen med en dansklærer. Testen er svær for mange af børnene. Emil er frustreret og urolig:

Joan tager Emil med ud (af klasselokalet) igen. De sætter sig i sofaen i fællesrummet. Han siger, at han savner sin mor. Han græder lidt. Joan sidder ved siden af og ser på ham, hun rører let ved hans arm og hans hår. 'Det er OK', siger hun. 'Det kan man godt komme til, hvis man har en øv-dag. Hvornår skal du hjem i dag? Skal vi tjekke det?'

Overvågningsaspektet og den sanktionerende funktion som omvendt bodyguard er her i spil, men Joan glider, idet tærsklen til klasserummet overskrides, over i rollen 
som vilkårlig omsorgsgiver. Da de sidder i sofaen, i det svagere kodede fællesrum, bliver relationen og anerkendelsen af Emil central. Omsorgsgerning og rum komplementerer hinanden. Eksemplet anskueliggør, hvordan pædagoger i det daglige arbejde håndterer og balancerer det pædagogiske paradoks mellem kvalifikation og inklusion.

\section{Rum for kvalifikation, plads til inklusion? - afsluttende diskussioner af et paradoks}

I artiklen har vi spurgt til, hvilke rum og roller pædagoger skaber i spændingsfeltet mellem kvalifikation og inklusion. Analyser af mødet mellem rum, børn og pædagogik illustrerer det hverdagslige og konkrete paradoks mellem en blød og en hård funktionalisme, som pædagoger igennem forskellige roller håndterer i praksis. Gennem aktiviteter og prioriteringer bidrager pædagogerne almindeligvis til at opretholde de kodninger, som rummene konnoterer, om end de undertiden også overskrider rummenes vanlige funktioner.

De tre gennemgående roller, som vi har beskrevet og analyseret, er pædagogernes måde at håndtere og balancere kravene om henholdsvis at kvalificere børnene fagligt og samtidig arbejde for mere inkluderende læringsmiljøer. Umiddelbart indeholder de tre roller forskellige vægtninger af og tilgange til kvalifikation og inklusion, som får betydning for, hvordan pædagogen arbejder med og konstruerer forholdet imellem individ og fællesskab og hvilke mulighedsrum, der kan skabes i forskellige sammenhænge. Det er dette forhold vi diskuterer i det følgende.

Vender vi i første omgang blikket mod rollen som klasserumsleder, prioriteres primært fællesskabet, nærmere bestemt det kollektive læringsudbytte og klassens samlede effektivitet. Prioriteringen forekommer legitim i vor aktuelle samtid, hvor en betydelig del af skolens fokus og pædagogiske narrativ vedrører elevernes faglige udbytte og folkeskolens internationale konkurrenceevne. Fokus på kvalifikation medfører naturligt en optagethed af effektiv og synlig faglig fremdrift. Bestræbelserne fører ofte til arbejdsbetingelser, der inviterer til disciplinering af den enkelte, så kollektivet uhindret kan arbejde. Disciplineringen giver implicit dessiner til det øvrige fællesskab om acceptabel adfærd: "I klasserommet foregår det et kontinuerlig arbeid med å innarbejde en felles forståelse for hva som er riktige måter å tenke, handle og snakke på. Grensen for det akseptable bliver giort tydelig gjennom irettesettelser av enkeltbarn, og små episoder fryses fast og giøres til skoleeksempler for mer prinsipielle vurderinger" (Lidén, 2000, s. 207). Sådanne pædagogiske strategier konnoterer umiddelbart integration (Hansen, 2006; Madsen, 2009). Dermed taber inklusionsidealet terræn og reduceres til et spørgsmål om selvinklusion (jf. Khawaja \& Knudsen, 2015), dvs. den enkeltes evner til at (tilpasse sin adfærd, så vedkommende kan) blive inkluderet. Dette favoriserer givetvis de mere robuste elever, der i forvejen har sans for de adfærdsmæssige koder i de pædagogiske rum. For at honorere klasserummets hårde funktionalisme regulerer pædagogerne børnenes adfærd og indskrænker mulighedsrummet. Forskellighed virker forstyrrende for den faglige rettethed og betragtes ofte som en byrde i undervisningen. Det betragtes grundlæggende som 
problematisk, når en elev eller en mindre gruppe elever forstyrrer de andre elevers læringsproces og ikke overholder rummets og pædagogikkens koder.

I rollen som omvendt bodyguard har pædagogen ikke længere ansvaret for klasserumsledelsen og det faglige indhold. Derfor forskyder pædagogens fokus sig og blikket rettes mod den enkelte elev. Gennem overvågning, sanktioner, inddelinger og afskærmninger i det fysiske rum, forebygger pædagogen uro og korrigerer adfærd. Fra mere perifere placeringer i klasserummet sætter pædagogen ind, hvor der opstår behov. I nogle tilfælde ekskluderer pædagogerne urolige børn og følger dem ud af klasserummet, men i de fleste tilfælde forsøger pædagogerne at fastholde børnene i klassen ved at støtte dem fagligt og hjælpe til - øjensynlig for at fastholde intentionen om at arbejde inkluderende. Desuagtet pædagogerne således ofte støtter og hjælper de sårbare eller mere urolige børn, så ser vi sjældent tegn på, at fællesskabet eller pædagogikken tilpasser sig den enkelte eller aktivt indstiller sig på de fagligt svagere børns arbejdstempo og formåen. En entydig løsning på, hvordan balancen imellem skolens øgede faglige krav og idealet om inklusion kan håndteres, synes rollen som omvendt bodyguard heller ikke at kunne levere.

Hvor rollerne som klasserumsleder og omvendt bodyguard primært lægger sig i forlængelse af hård funktionalisme og oftest fungerer i stærkt kodede omgivelser med relativt veldefinerede og begrænsede mulighedsrum, er rollen som vilkårlig omsorgsgiver mere åben og fleksibel. Oftere tager den form i de rum der konnoterer variation, dynamik og frivillighed, og pædagogen fokuserer på det relationelle aspekt og børnenes trivsel. Anerkendelse, ro, lydhørhed og accept af børns langsomhed kendetegner rollen og fokus er, som i tilfældet med den omvendte bodyguard, oftere rettet mod den enkelte. Dette fokus er dog i modsætning til rollen som omvendt bodyguard, tonet af et trivselsperspektiv fremfor et disciplineringsperspektiv og et fagligt ønske eller ideal om plads til den enkelte.

Biesta har i en række sammenhænge diskuteret uddannelse, og oplister tre domæner, der kendetegner skolens virke og værdigrundlag: kvalifikation, socialisering og subjektifikation (Biesta, 2011). I næsten al uddannelse er disse tre tilstede, men afhængig af tid og kontekst kan et af domænerne veje tungere end de to andre. En forfordeling af et domæne kan føre til spændinger domænerne imellem og en underprioritering af de resterende to (Biesta, 2015). Pædagogen knytter gennem forvaltningen af de tre roller på tværs af skole- og SFO-rummene an til alle tre domæner. I rollen som klasserumsleder er elevernes kvalifikationer i fokus. I rollen som omvendt bodyguard er børnenes socialisering i fokus, og i rollen som vilkårlig omsorgsgiver har frigørende og subjektive aspekter af børnenes dagligliv forrang. En sådan opdeling giver analytisk overskuelighed, men er for rigid og usmidig, når hverdagens variationer tages i betragtning. For naturligvis er det sådan, at pædagogerne i praksis pendler ind og ud af de forskellige roller, og sjældent inkarnerer dem så stilrent, som analysen ovenfor undertiden antyder. Således kan de tre roller, som vi har omtalt $i$ artiklen langtfra indfange den variation og kompleksitet, der kendertegner og udgør pædagogers arbejde i skole og SFO. Med de forbehold må analyserne læses. Med det sagt synes koblingen af rollerne og rummene til Biestas tre domæner dog at løfte sløret for, hvilken vægtning og balance, der aktuelt synes fremherskende i den 
danske skole- og fritidspædagogik. Med skolereformens flere timer på skoleskemaet nyder kvalifikationsdomænet større fokus og leder måske endda an. Biesta formulerer, at skolen fremstår "som en funktion af og en funktion for samfundet, hvor den perfekte skole er den skole, der varetaget funktionen bedst: friktionsfrit, effektivt, virkningsfuldt og uden alt for megen ballade" (Biesta, 2015, s. 106). Når børn skal lare noget, indtager pædagogerne som oftest rollen som klasserumsleder, der udleves i stærkt kodede rum med mindre plads til forskellighed, variation og selvstændighed. Den bløde funktionalisme, der karakteriserer SFO-rummene, og som oftere er bemandet af pædagoger, der agerer vilkårlige omsorgsgivere, knytter i højere grad an til subjektifikation og de individuelle og frigørende elementer, som er gældende der. Denne del af pædagogens arbejde aktiveres i dag vilkårligt og når det kan passes ind. Imellem rollerne som klasserumsleder og vilkårlig omsorgsgiver står den omvendte bodyguard, som på flere måder kan relateres til begrebet socialisering. Men som nævnt ovenfor er det siældent så enkelt. For når pædagogen arbejder i klasserummet indeholder pædagogikken og bestræbelserne selvfølgelig både elementer af kvalifikation, socialisation og subjektifikation, ligesom det naturligvis også gælder, når pædagogen har sin tid i SFO'en. For her lærer børn også. Om noget, om sig selv og om hinanden.

\section{Konklusion}

Vi har i denne artikel interesseret os for mødet mellem børn, rum og pædagogik i den danske folkeskole og diskuteret dilemmaet mellem kvalifikation og inklusion. Hvordan fremtidens skole i Danmark kommer til at se ud, kan analyserne ikke give fyldestgørende svar på, men artiklen bidrager, på baggrund af kvalitative empiriske data, til en problematisering af det aktuelle politiske og pædagogiske fokus på kvalifikation, herunder reduktionen af SFO-timer i børnenes hverdag. I artiklen har vi søgt at illustrere, hvilken betydning dette fokus har for pædagogers arbejde i skoleog fritidspædagogikken, og hvordan kvalifikationsbestræbelserne ofte og på forskellig vis kolliderer med intentionen om inklusion, når pædagogikken i klasserummene tager former, der mere konnoterer selvinklusion, tilpasning og traditionel integration.

\section{Om forfatterne}

David Thore Gravesen, Lektor og ph.d. ved VIA Pædagogik og Samfund. Programkoordinator i programmet Børn og Unges Hverdagsliv i Forsknings- og Udviklingscenteret VIA Kultur og Pædagogik. Har forsket i pædagogers professionelle karrierer, social reproduktion i børnehaver, ungdomskultur og boligkvarterets betydning for unges uddannelsesstrategier.

Lea Ringskou, Lektor og koordinator for skole- og fritidspædagogik ved VIA Pædagogik og Samfund. Har udført forskning indenfor Videnscenter for Social inklusion og Deltagelse og er i skrivende stund videnmedarbejder og forsker i programmet Estetik og Pcedagogik i Forsknings- og Udviklingscenteret VIA Kultur og Pædagogik.

\section{Referanser}

Alenkær, R. (Red.) (2009). Den inkluderende skole. København: Frydenlund.

Biesta, G. (2011). God uddannelse $i$ målingens tidsalder - etik, politik og demokrati. Århus: KLIM.

Biesta, G. (2015). Hvad skal vi stille op med børnene? Om uddannelse, modstand og dialogen mellem barn og verden. I J. Klitmøller \& D. Sommer (Red.), Lering, dannelse og udvikling (s. 105-123). København: Hans Reitzels Forlag. 
Buus, A. (2014). Inclusion as an objective for pedagogical practice. I E. Hygum \& P. M. Pedersen (Red.), Early Childhood Education (s. 63-77). Århus: VIA Systime.

Coninck-Smith, N. (2005). Ej blot til lyst. I K. Larsen, Arkitektur, krop og laring (s. 69-87). København: Hans Reitzels Forlag.

Dyssegaard, C. B. (2009). Inkluderende padagogik: intentioner og virkelighedens verden. Århus: Danmarks Pædagogiske Universitetsskole.

Dyssegaard, C. B., Larsen, M. S. \& Tiftikci, N. (2013). Effekt og pcedagogisk indsats ved inklusion af børn med scerlige behov $i$ grundskolen - systematisk review. Aarhus: Dansk Clearinghouse for Uddannelsesforskning, Aarhus Universitet.

Ehn, B. \& Löfgren, O. (2006). Kulturanalyser. Århus: Klim.

Foucault, M. (2002/1975). Overvågning og straf. København: Det lille forlag.

Gulløv, E. \& Højlund, S. (2005). Materialitetens pædagogiske kraft. I K. Larsen (Red.), Arkitektur, krop og laring (s. 21-42). København: Hans Reitzels Forlag.

Halkier, B. (2002). Fokusgrupper. København. Samfundslitteratur.

Hansen, J. H. (2006). Individ og fællesskab - om inklusion og eksklusion. I C. Schou \& C. Pedersen, Samfundet $i$ pedagogisk arbejde (s. 155-188). København: Akademisk Forlag.

Hansen, O. \& Qvortrup, L. (2013). Inklusion i Danmark - hvilke konsekvenser har begrebsdefinitioner for den pædagogiske praksis? Paideia, 5, 8-18.

Hastrup, K. (2010). Feltarbejde. I S. Brinkmann \& L. Tanggaard (Red.), Kvalitative metoder. København: Hans Reitzels Forlag.

Juelskjær, M. (2008). Rummenes modstand. Subjektivering set i et spatielt perspektiv. I J. Kofod \& D. Staurnæs (Red.), Magtballader. København: Danmarks Pædagogiske Universitetsforlag.

Khawaja, I. \& Knudsen, H. (2015). Når inklusion bliver til selv-inklusion. Undervisningsministeriet. Hentet fra http://www.emu.dk/sites/default/files/N\%C3\%A5r inklusion bliver selv-inklusion.pdf

Kirkeby, I., Gitz-Johansen, T. \& Kampmann, J. (2005). Samspil mellem fysisk rum og hverdagsliv i skolen. I K. Larsen (Red.), Arkitektur, krop og lering (s. 43-69). København: Hans Reitzels Forlag.

Knudsen, L. K. (2010). Nysyn på folkeskolen. København: Kommunernes Landsforening.

Kornerup, I. (2009). Inklusion som begreb og styringsredskab. I C. Pedersen, M. B. Larsen, I. Kornerup \& B. Madsen (Red.), Inklusionens padagogik (s. 41-72). København: Hans Reitzels Forlag.

Kristiansen, S. \& Krogstrup, H. K. (1999). Deltagende observation. København: Hans Reitzels Forlag.

Kvale, S. \& Brinkmann, S. (2008). Interview. København: Hans Reitzels Forlag.

Larsen, K. (2005). Indledning. I K. Larsen, Artitektur, krop og lering (s. 7-20). København: Hans Reitzels Forlag.

Lidén, H. (2000). Barn - tid - rom - skiftende posisjoner: Kulturelle laereprocesser $i$ et pluralistisk Norge. Trondheim: Norges teknisk-naturvitenskapelige universitet.

Madsen, B. (2009). Inklusionens pædagogik - om at vide, hvad der ekskluderer for at udvikle en pædaggik, der inkluderer. I C. Pedersen, M. B. Larsen, I. Kornerup \& B. Madsen (Red.), Inklusionens predagogik (s. 11-35). København: Hans Reitzels Forlag.

Small, M. L. (2008). "Lost in Translation: How Not to Make Qualitative Research More Scientific". I M. Lamont \& P. White (Red.), Report from Workshop on Interdisciplinary Standards for Systematic Qualitative Research. Washington, DC: National Science Foundation.

Spradley, J. (1980). Participant Observation. Wadsworth: Thomson Learning.

Stanek, A. H. (2012a). Pædagogers bidrag til skolen. I P. Hviid \& C. Højholdt, Fritidspadagogik og børneliv (102-129). København: Hans Reitzels Forlg.

Stanek, A. H. (2012b). Ukoncentreret? - eller koncentreret om de andre børn. Pcedagogisk Psykologisk Tidsskrift. December, 2012, 392-398.

Thomsen, L. O. (2014). Folkeskolereform giver mulighed for mere og bedre inklusion. Danmark: Kommunernes Landsforening. Hentet fra 3.2.2016 http://www.kl.dk/Folkeskolen1/Folkeskolereform-giver-mulighed-formere-og-bedre-inklusion-id148310/ 